\title{
Light Response of Retinal ON Bipolar Cells Requires a Specific Splice Variant of $\mathrm{G} \alpha_{\text {o }}$
}

\author{
Anuradha Dhingra, ${ }^{* *}$ Meisheng Jiang, ${ }^{3 *}$ Tian-Li Wang, ${ }^{1 *}$ Arkady Lyubarsky, ${ }^{2}$ Andrey Savchenko, ${ }^{2}$ \\ Tehilla Bar-Yehuda, ${ }^{1}$ Peter Sterling, ${ }^{1}{ }^{\text {Lutz Birnbaumer, }}{ }^{3}$ and Noga Vardi ${ }^{1}$ \\ Departments of ${ }^{1}$ Neuroscience and ${ }^{2}$ Ophthalmology, University of Pennsylvania, Philadelphia, Pennsylvania 19104, and \\ ${ }^{3}$ Department of Anesthesiology, University of California, Los Angeles, Los Angeles, California 90024
}

Glutamate released onto retinal ON bipolar neurons binds to a metabotropic receptor to activate a heterotrimeric G-protein $\left(G_{o}\right)$ that ultimately closes a nonspecific cation channel. Signaling requires the $\alpha$ subunit $\left(\mathrm{G} \alpha_{\mathrm{o}}\right)$, but its effector is unknown. Because $\mathrm{G} \alpha_{\mathrm{o}}$ is transcribed into two splice variants ( $\alpha_{\mathrm{o} 1}$ and $\alpha_{\mathrm{o} 2}$ ) that differ in the key GTPase domain, the next step in elucidating this pathway was to determine which splice variant carries the signal. Here we show by reverse transcription-PCR and Western blots that retina expresses both splice variants. Furthermore, in situ hybridization and immunostaining on mouse retina deficient in one splice variant or the other show that both $\alpha_{\mathrm{o} 1}$ and $\alpha_{\mathrm{o} 2}$ are expressed by $\mathrm{ON}$ bipolar cells but that $\alpha_{\mathrm{o} 1}$ is much more abundant. Finally, electroretinography performed on mice deficient for one splice variant or the other shows that the positive b-wave (response of ON bipolar cells to rod and cone input) requires $\alpha_{\mathrm{o} 1}$ but not $\alpha_{\mathrm{o} 2}$. Thus, the light response of the $\mathrm{ON}$ bipolar cell is probably carried by its strongly expressed splice variant, $\mathrm{G} \alpha_{\mathrm{o} 1}$.

Key words: G-protein; $G_{0}$ splice variants; splice variant knock-out mouse; mGluR6; metabotropic glutamate receptor; retina; $E R G$
At the first visual synapse, glutamate modulates three-quarters of the postsynaptic neurons (ON bipolar cells) via a metabotropic glutamate receptor (mGluR6) (Nomura et al., 1994; Vardi and Morigiwa, 1997; Vardi et al., 1998, 2000) that couples to a heterotrimeric G-protein $\left(\mathrm{G}_{\mathrm{o}}\right)$ (Weng et al., 1997; Nawy, 1999; Dhingra et al., 2000). Signaling requires the $\alpha$ subunit ( $\left.\mathrm{G} \alpha_{\mathrm{o}}\right)$, but, the next step in this pathway, which ultimately closes a nonspecific cation channel, is unknown (Nawy and Jahr, 1990; Shiells and Falk, 1990; de la Villa et al., 1995; Euler et al., 1996). To identify an effector for $\mathrm{G} \alpha_{\mathrm{o}}$ seems important even beyond the visual system because, although effectors are known for the $\beta / \gamma$ subunits of this most abundant brain G-protein (Dolphin, 1998), no effectors have yet been identified for the $\alpha$ subunit.

$\mathrm{G} \alpha_{\mathrm{o}}$ is transcribed into two splice variants, $\alpha_{\mathrm{o} 1}$ and $\alpha_{\mathrm{o} 2}$, which contain identical helical domains near the $\mathrm{N}$ terminus (NT) but different GTPase domains near the $\mathrm{C}$ terminus (CT) (Goldsmith et al., 1988; Hsu et al., 1990; Strathmann et al., 1990; Tsukamoto et al., 1991; Horn and Latchman, 1993). Because the GTPase domain binds both receptor and effector, it is crucial for coupling (for review, see Neer, 1994; Clapham, 1996; Gudermann et al., 1997). Therefore, the next step in elucidating this pathway was to determine which splice variant carries the signal. Previous studies that colocalized $\mathrm{G} \alpha_{\mathrm{o}}$ with mGluR6 in ON bipolar dendrites could

\footnotetext{
Received Jan. 18, 2002; revised March 27, 2002; accepted April 3, 2002.

This work was supported by National Eye Institute Grants EY11105 (N.V.), EY00828 (P.S.), and EY02660 (E.N.P.), the Research to Prevent Blindness Foundation (E.N.P.), and National Institutes of Health Grant DK19318 (L.B.). We thank Yi-Jun Shi and Sally Shrom for excellent technical assistance. We also thank David Manning for donating the antibodies for $\mathrm{G} \alpha_{\mathrm{o}}$ (C terminus), $\mathrm{G} \alpha_{\mathrm{o} 1}$, and $\mathrm{G} \alpha_{\mathrm{o} 2}$ and Kwen-Jen Chang for donating the antibody for $\mathrm{G} \alpha_{\mathrm{o}}$ ( $\mathrm{N}$ terminus).

*A.D., M.J., and T.-L.W. contributed equally to this work.

Correspondence should be addressed to Dr. Anuradha Dhingra, 123, Anat-Chem Building, Department of Neuroscience, University of Pennsylvania, Philadelphia, PA 19104. E-mail: annu@retina.anatomy.upenn.edu.

T.-L. Wang's present address: Howard Hughes Medical Institute and Johns Hopkins Oncology Center, The Johns Hopkins University, Baltimore, MD 21231. Copyright (C) 2002 Society for Neuroscience $\quad 0270-6474 / 02 / 224878-07 \$ 15.00 / 0$
}

not distinguish between different splice variants because the antibody (Ab) used recognizes both (Vardi, 1998), nor did the $\alpha_{\mathrm{o}}$ null mouse, which lacks the $\mathrm{ON}$ response, resolve this question because it is missing both splice variants (Jiang et al., 1998; Dhingra et al., 2000). Here, using mice deficient in one splice variant or the other, we show that both are expressed by $\mathrm{ON}$ bipolar dendrites but that only $\mathrm{G} \alpha_{\mathrm{o} 1}$ matters for the light response.

\section{MATERIALS AND METHODS}

Animals were deeply anesthetized by intraperitoneal injection (for rat, $45 \mathrm{mg} / \mathrm{kg}$ pentobarbital; for mouse, a mixture of $85 \mu \mathrm{g} / \mathrm{gm}$ ketamine and $13 \mu \mathrm{g} / \mathrm{gm}$ xylazine), and the eyes were enucleated; animals were then killed by anesthetic overdose (three times the initial doses). Animals were treated in compliance with federal regulations and University of Pennsylvania policy. The eye was incised at the ora serata and fixed by immersion in buffered 3 or $4 \%$ paraformaldehyde with (for immunocytochemistry) or without (for in situ hybridization) $0.01 \%$ glutaraldehyde for $1 \mathrm{hr}$. It was then rinsed in buffer, soaked overnight in $30 \%$ buffered sucrose, and embedded in a mixture of two parts $20 \%$ sucrose in phosphate buffer and one part of tissue freezing medium. Radial cryosections were $10-15 \mu \mathrm{m}$ thick.

Reverse transcription-PCR. Retina was homogenized in solution containing $4 \mathrm{~m}$ guanidium thiocyanate, $25 \mathrm{~mm}$ sodium citrate, $0.5 \%$ sarcosyl, and $0.1 \mathrm{~m}$ 2-mercaptoethanol, and total RNA was isolated by the acidguanidium phenol-chloroform method (Chomczynski and Sacchi, 1987). The reverse transcription (RT) reaction was performed at $42^{\circ} \mathrm{C}$ for 50 min with $1-5 \mu \mathrm{g}$ of total RNA in $20 \mu \mathrm{l}$ of buffer containing $50 \mathrm{~mm}$ Tris-HCl, pH 7.4, $60 \mathrm{~mm} \mathrm{KCl}, 10 \mathrm{~mm} \mathrm{MgCl}, 1 \mathrm{~mm}$ DTT, $1 \mathrm{U} / \mathrm{ml}$ RNase inhibitor, $0.5 \mathrm{~mm}$ of each dNTP, 500 pmol of random hexamer (or 100 pmol of oligo-dT), and $200 \mathrm{U}$ of SuperScript II Moloney murine leukemia virus reverse transcriptase (Invitrogen, Gaithersburg, MD). PCR reaction was performed in a buffer containing $10 \mathrm{~mm}$ Tris, $\mathrm{pH} 8.3,50 \mathrm{~mm}$ $\mathrm{KCl}, 2.5 \mathrm{mM} \mathrm{MgCl}_{2}, 0.4 \mathrm{~mm} \mathrm{dNTP}, 0.2 \mu \mathrm{M} 5^{\prime}$ and $3^{\prime}$ primers, $2 \mu \mathrm{l}$ of reverse-transcribed cDNA, and $2.5 \mathrm{U}$ of AmpliTaq (PerkinElmer Life Sciences, Branchburg, NJ). Thirty cycles $\left(94^{\circ} \mathrm{C}\right.$ for $1 \mathrm{~min}, 52^{\circ} \mathrm{C}$ for $1 \mathrm{~min}$, and $72^{\circ} \mathrm{C}$ for $2 \mathrm{~min}$ ) were performed on a programmable thermocycler (PerkinElmer Life Sciences). The sequences of PCR primers (synthesized by Invitrogen) were the same as those used to generate the long probe for in situ hybridization (see below). 
In situ hybridization. $\alpha_{\mathrm{o} 1}$ and $\alpha_{\mathrm{o} 2}$ sequences were amplified by RT-PCR from whole retina. The sequences of PCR primers were as follows: $\alpha_{\mathrm{o} 1}$ upstream, 5'-catcctccgaaccagggtc-3'; $\alpha_{\mathrm{o} 1}$ downstream, 5'-caagccacagccccggag-3'; $\alpha_{\mathrm{o} 2}$ upstream, 5'-catcctccgaaccagggtc-3'; and $\alpha_{\mathrm{o} 2}$ downstream, 5'-ggcgatgatgacgtccgt- $3^{\prime}$. We also designed a set of probes at the most diverse region of $\alpha_{\mathrm{o}}$ (which gave a shorter reaction product): $\alpha_{\mathrm{o} 1}$ upstream, $5^{\prime}$-gctcttcgactccatctgt- $3^{\prime} ; \alpha_{\mathrm{o} 1}$ downstream, same as for the first set; $\alpha_{\mathrm{o} 2}$ upstream, 5'-gacagcatctgcaacaac-3'; and $\alpha_{\mathrm{o} 2}$ downstream, same as for the first set. PCR products were subcloned into PCRII vector (Invitrogen) or pBluescript (Stratagene, La Jolla, CA), and the authenticity of the products was verified by direct sequencing. ${ }^{33} \mathrm{P}$-labeled riboprobe was made by in vitro transcription. Briefly, the reaction was performed by incubating the linearized plasmid DNA in $20 \mu$ l of solution containing $40 \mathrm{U}$ of RNA polymerase, $10 \mathrm{~mm}$ DTT, $20 \mathrm{U}$ of RNase inhibitor, $0.5 \mathrm{~mm}$ ATP, GTP, and CTP, $250 \mu \mathrm{M} \mathrm{UTP}$, and $25 \mu \mathrm{Ci}$ of $\left[\alpha-{ }^{33} \mathrm{P}\right] \mathrm{UTP}$. After incubating at $37^{\circ} \mathrm{C}$ for $2 \mathrm{hr}$, the reaction was treated with RNase-free DNase I and precipitated by LiCl. RNA was further purified by phenol-chloroform extraction, precipitated by ethanol, and finally dissolved in DEPC water.

To test whether the antisense probes cross-hybridized, we applied the sense transcripts of $\alpha_{\mathrm{o} 1}$ and $\alpha_{\mathrm{o} 2}$ to a nitrocellulose membrane and then tried to hybridize them with the antisense probes. Each antisense hybridized to its own sense but not to the other; therefore, the in situ hybridization probably reflects genuine distribution of $\alpha_{\mathrm{o} 1}$ and $\alpha_{\mathrm{o} 2}$ mRNAs.

Retina sections were hybridized overnight $(\sim 18 \mathrm{hr})$ with ${ }^{33} \mathrm{P}$-labeled probes in in situ hybridization buffer containing $10 \%$ dextran sulfate, $50 \%$ formamide, $4 \times \mathrm{SSC}, 0.1 \% \mathrm{SDS}$, and $2 \times$ Denhardt's solution at $10^{6}$ $\mathrm{cpm} / 50 \mu \mathrm{l}$. After overnight hybridization at 58 or $65^{\circ} \mathrm{C}$, slides were washed twice at $10^{\circ} \mathrm{C}$ above the hybridization temperature in $2 \times \mathrm{SSC}-$ $50 \%$ formamide, once at room temperature in $2 \times \mathrm{SSC}$, followed by one wash at $10^{\circ} \mathrm{C}$ above the hybridization temperature in $1 \times \mathrm{SSC}-0.1 \% \mathrm{SDS}$. Slides were rinsed in $0.1 \times$ SSC, incubated with $300 \mathrm{~mm}$ ammonium acetate, dehydrated in ethanol, and finally dipped in photographic emulsion (Kodak NTB-2; Eastman Kodak, Rochester, NY) and exposed for 1-5 weeks.

Immunocytochemistry. Staining was performed according to a standard protocol: soak in diluent containing 10\% normal goat serum, $5 \%$ sucrose, and $0.3 \%$ Triton $\mathrm{X}-100$ in phosphate buffer; incubate in primary antibodies overnight at $4^{\circ} \mathrm{C}$; wash and incubate $(3 \mathrm{hr})$ in anti-rabbit $\mathrm{F}(\mathrm{ab})_{2}$ fragment conjugated to a fluorescent marker; and rinse and mount in Vectashield (Vector Laboratories, Burlingame, CA). To stain a $4 \%$ paraformaldehyde-fixed retina for protein kinase $\mathrm{C}$ (PKC), we needed to retrieve the antigenicity with $0.5 \%$ sodium borohydrate $(8 \mathrm{~min})$ and use both Triton X-100 $(0.75 \%)$ and Tween $20(0.2 \%)$ as detergents. For double staining, incubation was done as for single labeling, with both primary antibodies and both secondary antibodies simultaneously. Some sections were incubated in horseradish peroxidase-conjugated secondary antibody and visualized with 3,3'-diaminobenzidine (DAB) reaction product. For electron microscopy, DAB reaction product was intensified by the gold-substituted silver-intensified peroxidase method. The tissue was then osmicated $(1.5 \%$ osmium tetroxide, $60 \mathrm{~min})$, stained with $1 \%$ uranyl acetate in $70 \%$ methanol (60 min), dehydrated in 80,90 , and $100 \%$ methanol, cleared in propylene oxide, and embedded in Epon 812. Ultrathin sections were mounted on Formvar-coated slot grids and stained with uranyl acetate.

Antibodies. The antibody against $\alpha_{\mathrm{o} 1}$ (Ab 1718) was raised in rabbit against the peptide EYPGSNTYED, and the antibody against $\alpha_{\mathrm{o} 2}(\mathrm{Ab}$ 1715 ) was prepared against peptide EYTGPSAFTE (both are gifts from Dr. D. Manning, University of Pennsylvania, Philadelphia, PA). In addition, three antibodies against $\alpha_{\mathrm{o}}$ that recognize both splice variants on Western blots were used. (1) A polyclonal antibody (Ab 9072) was raised in rabbit against the peptide ANNLRGCGLY located at the C terminus (gift from Dr. D. Manning). This sequence is identical to that of $\alpha_{\mathrm{o} 1}$ peptide but is different in one amino acid from the corresponding peptide of $\alpha_{\mathrm{o} 2}$ (in which the bolded asparagine is replaced by lysine). (2) A polyclonal antibody was raised in rabbit against a peptide DGISAAKDV located at the $\mathrm{N}$ terminus (gift from Kwen-Jen Chang, The Burroughs Wellcome Co., Research Triangle Park, NC) (Chang et al., 1988; Codina et al., 1991). This peptide is identical in both splice variants. (3) A monoclonal antibody (mAb 3073) raised in mouse against the purified bovine protein (Chemicon; Li et al., 1995). The antibody to PKC $\alpha$ was monoclonal raised in mouse (mAb 5; Amersham Biosciences, Little Chalfont, UK).

Selective disruption of $G \alpha_{o 1}$ and $G \alpha_{o 2}$ expression. Standard molecular biology techniques, to be reported in detail elsewhere, were used to construct targeting vectors of two types (Rudolph et al., 1993, 1994; Jiang et al., 2002). For disruption of $\mathrm{G} \alpha_{\mathrm{o} 1}$, a replacement-type targeting vector was made. It contained a genomic segment of the $\mathrm{G} \alpha$ o gene with exons 6 , $7.2,8.2,7.1,8.1$, and 9.1, of which exon 7.1 was disrupted by insertion of a neomycin selection cassette, followed by an internal ribosome entry site, and the open reading frame of $\beta$-galactosidase. $\mathrm{G} \alpha_{\mathrm{o} 1}$-targeted embryonic stem (ES) cells were obtained by selection for G418 resistant clones. For disruption of $\mathrm{G} \alpha_{\mathrm{o} 2}$, an insertion-type vector was made with the same genomic segment, but, instead of disrupting exon 7.1, the codon for Cys-255 of exon 7.2 was replaced by a stop codon. In addition, a double neomycin-thymidine kinase selection cassette was placed at the end of the genomic segment to allow for positive and negative selection strategies.

$\mathrm{G} \alpha_{\mathrm{o} 2}$-targeted ES cells were generated by the "hit-and-run" procedure in which insertion of the mutated homology and selection cassettes is selected for in the presence of G418, and subsequent excision of the wild-type duplicate with attending loss of both selection cassettes was obtained by negative selection in the presence of FIAU (2-fluoro,2deoxy-5-iodouracyl- $\beta$-D-arabinofuranoside). After germline transmission, the resulting F2 mice (50:50 129Sv/C57BJ/6) either lacked $\mathrm{G} \alpha_{\mathrm{o} 2}$ but preserved expression of $\mathrm{G} \alpha_{\mathrm{o} 1}$ or lacked $\mathrm{G} \alpha_{\mathrm{o} 1}$ but preserved expression of $\mathrm{G} \alpha_{\mathrm{o} 2}$ and, in addition, expressing $\beta$-galactosidase (M. Jiang and L. Birnbaumer, unpublished observations) (vide infra for differential $\mathrm{G}_{\mathrm{o}}$ protein expression data).

Electroretinographic recordings. The experimental apparatus, methods of light stimulation and quantification, electroretinographic (ERG) recording, and cone signal isolation have been described in detail previously (Lyubarsky et al., 1999, 2002). Briefly, a mouse was dark adapted for $2 \mathrm{hr}$, and then, under dim red light, it was deeply anesthetized by intraperitoneally injecting ketamine $(20 \mu \mathrm{g} / \mathrm{gm})$ plus xylazine $(8 \mu \mathrm{g} / \mathrm{gm})$. The animal was immobilized in a holder, the pupils were dilated with $1 \%$ tropicamide, and the eyes were protected with a drop of methylcellulose. A platinum recording electrode contacted both corneas, and a tungsten reference electrode was inserted subcutaneously on the forehead. The animal in its holder was then placed inside a light-proof Faraday cage, and light stimuli were delivered through several ports. Stimulus intensity and spectral composition were controlled with neutral density and bandpass interference filters. Light intensities were calibrated and converted to estimated numbers of photoisomerization per photoreceptor $\left(R^{*}\right)$ as described previously (Lyubarsky et al., 1999, 2000).

\section{RESULTS \\ Both splice variants of $\mathrm{G} \alpha_{\mathrm{o}}\left(\alpha_{\mathrm{o} 1}\right.$ and $\left.\alpha_{\mathrm{o} 2}\right)$ are expressed in retina}

To determine which transcripts are expressed, we first performed RT-PCR on rat whole retina. Both transcripts were amplified: the bands were at the expected sizes (530 for $\alpha_{\mathrm{o} 1}$ and 510 for $\alpha_{\mathrm{o} 2}$ ), and the PCR products were cut at the expected positions by the appropriate restriction enzyme (ClaI applied to $\alpha_{\mathrm{o} 1}$ and HindIII applied to $\alpha_{\mathrm{o} 2}$ ) (Fig. $1 A, B$ ). In several experiments in which the PCR products were sequenced, there was good agreement with published sequences for hamster $\alpha_{\mathrm{o} 1}$ or $\alpha_{\mathrm{o} 2}$ sequences.

To determine whether both proteins are expressed, we used antibodies specific for each splice variant. The specificity of the antibody was tested by dot blots: the antibody for $\alpha_{\mathrm{o} 1}$ reacted with the $\alpha_{\mathrm{o} 1}$ peptide but not with the $\alpha_{\mathrm{o} 2}$ peptide, and the antibody for $\alpha_{\mathrm{o} 2}$ reacted with the $\alpha_{\mathrm{o} 2}$ peptide but not with the $\alpha_{\mathrm{o} 1}$ peptide (Fig. $1 C)$. By SDS-PAGE of retinal homogenates followed by Western blotting, the $\alpha_{\mathrm{o} 1}$ antibody detected a prominent band at $\sim 43 \mathrm{kDa}$, and the antibody for $\alpha_{\mathrm{o} 2}$ detected a prominent band at $\sim 40 \mathrm{kDa}$; both agree with their known molecular weights of 40 and $39 \mathrm{kDa}$ (Fig. 1D). The antibody for $\alpha_{\mathrm{o} 2}$ detected an additional band at $\sim 50 \mathrm{kDa}$. We conclude that the retina expresses RNA transcripts and proteins of both splice variants of $\alpha_{\mathrm{o}}$.

\section{$\alpha_{\mathrm{o} 1}$ is expressed by rod bipolar cells}

First, we tested the distribution of $\alpha_{\mathrm{o} 1}$ mRNA by in situ hybridization. Antisense riboprobe for $\alpha_{\mathrm{o} 1}$ transcript applied to sections of fixed rat retina showed strong labeling in the inner nuclear 
A

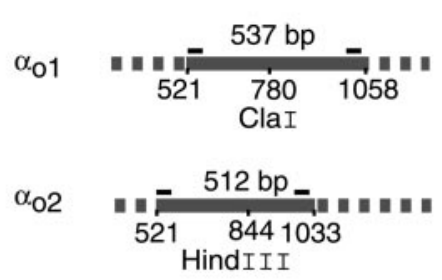

B

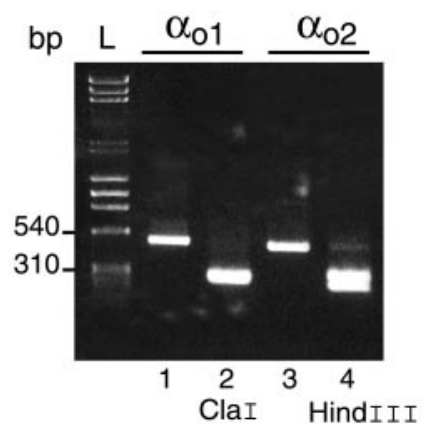

C

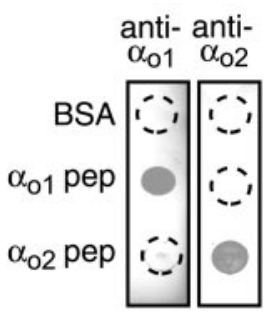

D

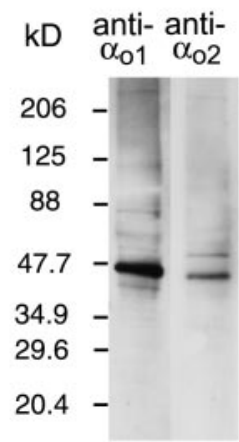

Figure 1. Retina expresses both splice variants of $\alpha_{\mathrm{o}}$. A, Primers for amplifying $\alpha_{\mathrm{o} 1}$ and $\alpha_{\mathrm{o} 2}$ mRNA; restriction enzymes cutting sites are also indicated. $B$, mRNA from rat retina was reverse transcribed and amplified using the specific primers shown in $A$. In lanes 2 and 4, the PCR products were cut with restriction enzymes. $C$, Dot blots show that $\alpha_{\mathrm{o} 1}$ antibody does not recognize the $\alpha_{\mathrm{o} 2}$ peptide ( $\alpha_{o 2}$ pep ) and that $\alpha_{\mathrm{o} 2}$ antibody does not recognize the $\alpha_{\text {o1 }}$ peptide $\left(\alpha_{o 1}\right.$ pep). Neither antibody reacted with bovine serum albumin $(B S A)$. D, Western blots of whole rat retina show, for $\alpha_{\mathrm{o} 1}$, a single prominent band at $\sim 43 \mathrm{kDa}$ and, for $\alpha_{\mathrm{o} 2}$, a prominent band at $\sim 40 \mathrm{kDa}$ plus a weak band at $\sim 50 \mathrm{kDa}$.

layer (INL) and ganglion cell layer. Labeling was strongest in the upper tiers of the INL, the location of rod bipolar cell somas. Labeling in the outer nuclear layer (ONL) and in photoreceptor inner segments was weak and was not significantly different from background obtained with sense probes for $\alpha_{\mathrm{o} 1}$ (Fig. 2A,B). A shorter, more specific probe gave less signal but the same labeling pattern. Also, the same probes applied to mouse retina gave weaker but similar labeling.

Next, we tested the distribution of $\alpha_{\mathrm{o} 1}$ protein. An antibody specific for this splice variant, applied to both rat and mouse retinas, showed staining similar to that obtained previously for $\alpha_{\mathrm{o}}$ (Vardi et al., 1993; Vardi, 1998). Stained somas were numerous in the upper tiers of the INL, with dendrites reaching high in the outer plexiform layer (OPL) (Fig. 2C,F). Electron microscopy showed the stain in dendrites that invaginate the rod terminal (data not shown). Thus, rod bipolar somas and dendrites stain for $\alpha_{\mathrm{o} 1}$. The bipolar axons crossing the INL were stained for $\alpha_{\mathrm{o} 1}$, but, as they cross the inner plexiform layer (IPL), they were unstained. The IPL was also stained but more weakly than OPL. By confocal microscopy, the IPL showed two intense strata at $\sim 25$ and $55 \%$ of IPL depth, a lack of stain between $\sim 25$ and $35 \%$, and weak stain elsewhere ( $0 \%$ is the interface between INL and IPL). Photoreceptors were unstained. Staining pattern for $\alpha_{\mathrm{o} 1}$ was specific because (1) retinal sections from rat incubated with preimmune serum or with antibody preabsorbed with the $\alpha_{\mathrm{o} 1}$ peptide were negative (Fig. 2D,E), and (2) retinal sections from an $\alpha_{\mathrm{o} 1}$ null mouse and an $\alpha_{\mathrm{o}}$ null mouse were negative (Fig. 2G,H).

\section{$\alpha_{\mathrm{o} 1}$ is expressed by all types of ON cone bipolar cell}

Because rod bipolar cells and ON cone bipolar cells differ in response kinetics, components of their transduction cascades
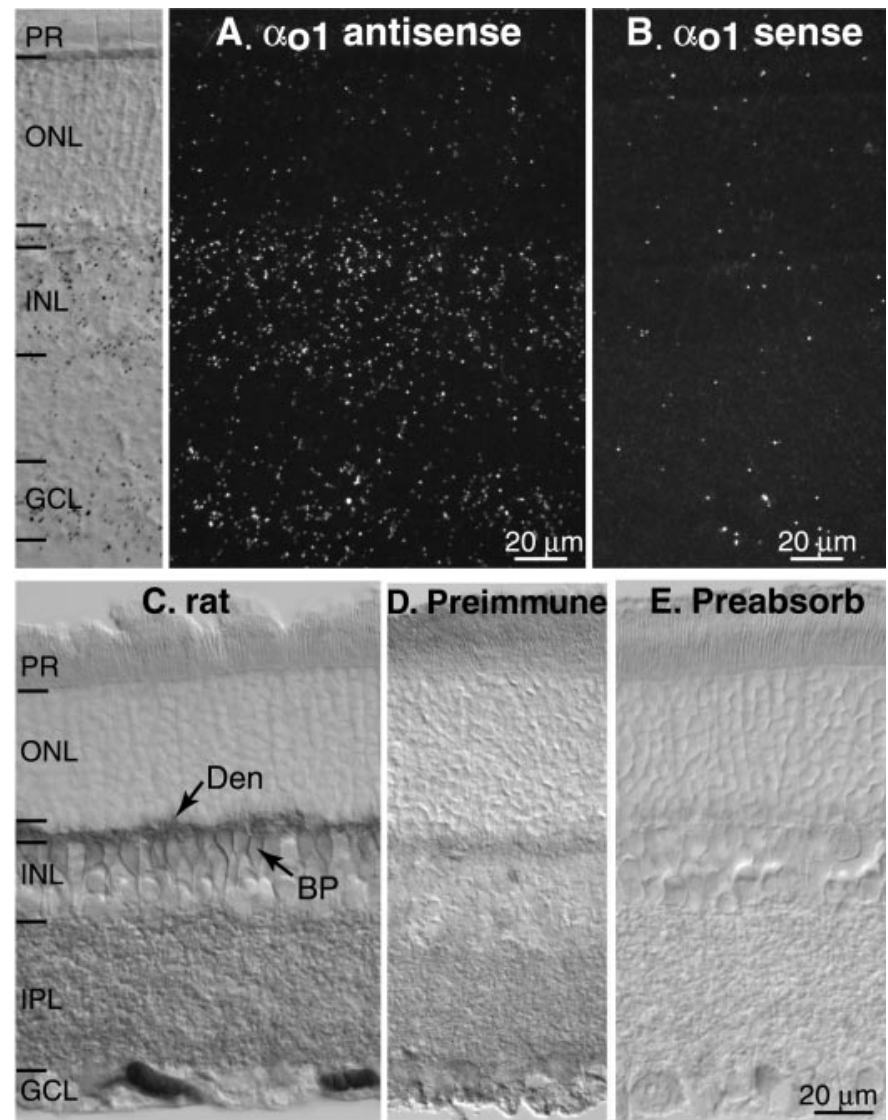

E. Preabsorb
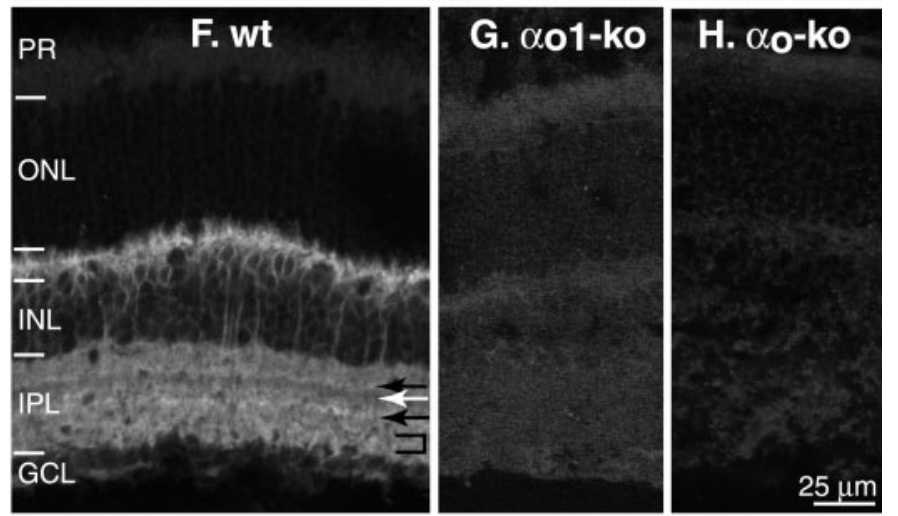

Figure 2. Bipolar cells strongly stain for the $\alpha_{\mathrm{o} 1}$ splice variant. $A, B$, In situ hybridization (rat). Antisense probe gave labeling in the INL and in the ganglion cell layer $(G C L)$. Strongest labeling is in the upper tier of the INL, the location of rod bipolar somas. Sense probe gave low background. Left panels, Differential interference contrast shows the retinal layers of the section in $A$. $P R$, Photoreceptors. $C-E$, Immunostaining with the $\alpha_{\mathrm{o} 1}$-specific antibody visualized with 3,3'-diaminobenzidine (rat). C, Staining is strong in bipolar dendrites (Den) in OPL and weaker in bipolar somas $(B P)$ in the INL and in the IPL. $D$, Staining with the preimmune serum was negative. $E$, Staining with the antibody preabsorbed with the $\alpha_{\mathrm{o} 1}$ peptide was also negative. $F-H$, Immunostaining with the $\alpha_{\mathrm{o} 1}$-specific antibody visualized with FITC (mouse). $F$, In the OPL and INL, staining in wild-type mouse resembles that in rat. In the IPL, note the thin bands of higher intensity (black arrows), a thicker band of lower intensity (brackets), and a band devoid of staining (white arrow). $G, H$, No staining above general background was observed when the same antibody was applied, respectively, to an $\alpha_{\mathrm{o} 1}$ or $\alpha_{\mathrm{o} 1+2}$ null mouse. ko, Knock-out; $w t$, wild type. 

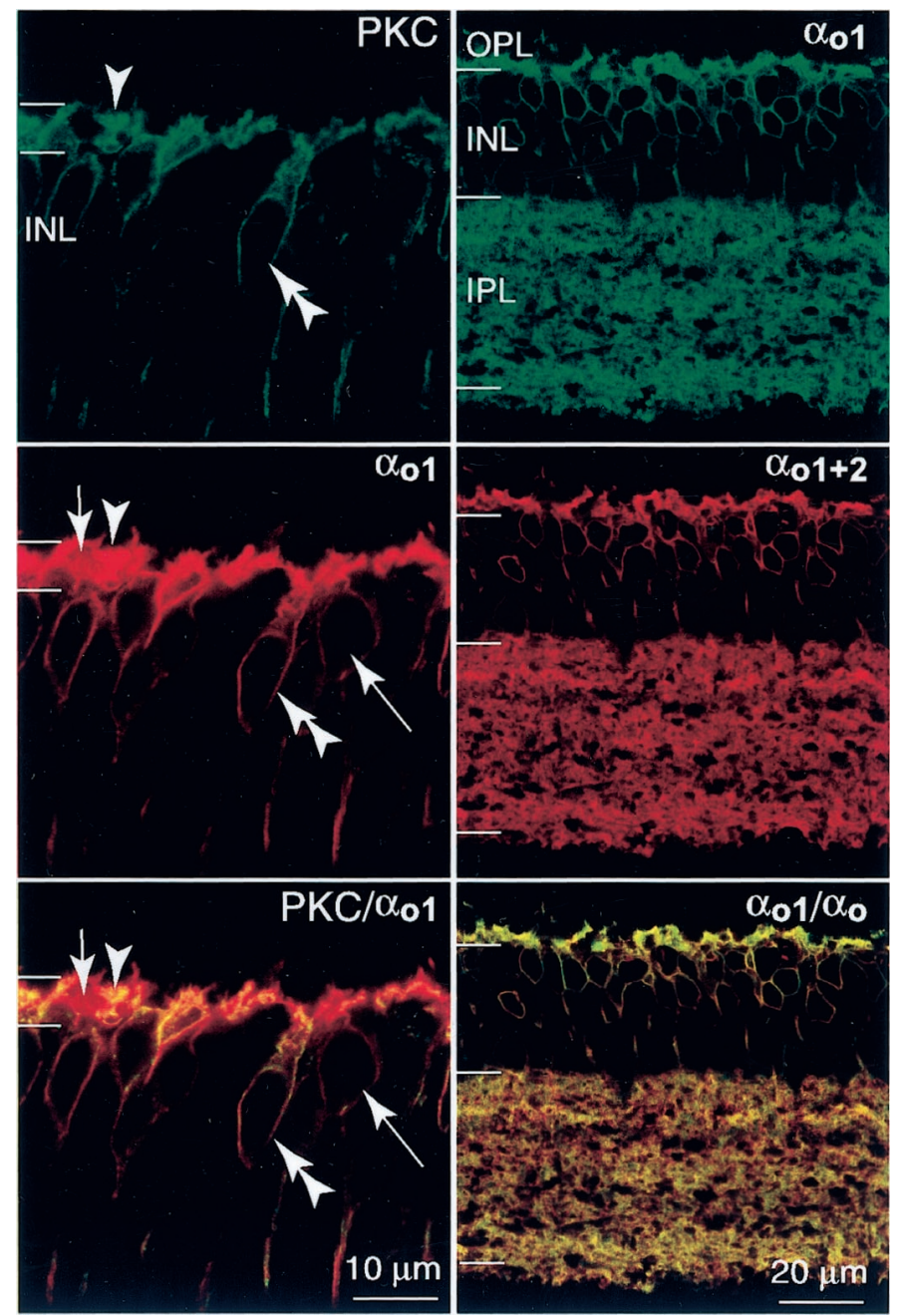

Figure 3. All ON cone bipolar cells stain for $\alpha_{\mathrm{o} 1}$ (rat). Left, All rod bipolar somas (stained for PKC) also stained for $\alpha_{\mathrm{o} 1}$ (double arrowhead), but some somas stained only for $\alpha_{\mathrm{o} 1}$ (long arrow). In the OPL (bracketed), rod bipolar dendrites stained for both PKC and $\alpha_{\mathrm{o} 1}$ (arrowhead), but some dendrites stained only for $\alpha_{\mathrm{o} 1}$ (short arrow). These probably belong to ON cone bipolar cells. Right, All ON bipolar somas were identified by staining with the monoclonal antibody for $\alpha_{\mathrm{o}}$. All of these somas also stained for $\alpha_{\mathrm{o} 1}$. Also, in the IPL, the two staining patterns were the same, indicating that the retina expresses primarily the $\alpha_{\mathrm{o} 1}$ splice variant.

might also differ (Berntson and Taylor, 2000; Wu et al., 2000). Therefore, we asked whether rod and cone bipolar cells express the same splice variant of $G_{0}$. Double immunostaining showed that all ON bipolar cells express $\alpha_{\mathrm{o} 1}$. First, rod bipolar cells identified with antibody for PKC stained for $\alpha_{\mathrm{o} 1}$, but additional somas positive for $\alpha_{\mathrm{o} 1}$ were negative for PKC; these are cone bipolar cells (Fig. 3, left). Similarly, rod bipolar dendritic terminals projecting high in the OPL stained for both PKC and $\alpha_{\mathrm{o} 1}$, but processes at midlevel in the OPL, in which cone bipolar dendrites terminate, stained only for $\alpha_{\mathrm{o} 1}$ (Fig. 3, left). Second, we labeled all ON bipolar cells using a monoclonal antibody for $\mathrm{G}_{\mathrm{o}}$. This antibody is suitable because it stains exactly the same set of cells as the antibody against the $\mathrm{C}$ terminus, which was shown to label all ON bipolar cells (Vardi, 1998). In this double staining, all somas stained by the monoclonal antibody also stained for $\alpha_{\mathrm{o} 1}$ (Fig. 3, right). Interestingly, stain for $\alpha_{\mathrm{o}}$ and $\alpha_{\mathrm{o} 1}$ completely colocalized, even in the inner plexiform layer, suggesting that in retina all the $\alpha_{\mathrm{o}}$-positive cells express at least the $\alpha_{\mathrm{o} 1}$ splice variant.

\section{ON bipolar cells and certain amacrine cells express low levels of $\alpha_{\mathrm{o} 2}$}

A specific antisense probe for $\alpha_{\mathrm{o} 2}$ mRNA distributed similarly to that of $\alpha_{\mathrm{o} 1}$ : strong labeling in the INL, somewhat weaker in the ganglion cell layer, and none in the outer nuclear layer and photoreceptor inner segments (Fig. 4A). A shorter, more specific probe distributed similarly, but less intensely, whereas the sense probe distributed randomly and rather weakly (Fig. 4B).

To test the distribution pattern of the $\alpha_{\mathrm{o} 2}$ protein was difficult. The antibody for $\alpha_{\mathrm{o} 2}$ capriciously stained cone outer segments in rat (but not in mouse), and it also stained Muller cells. The staining of the Muller cell was clearly unspecific because this cell also stained with the preimmune serum applied to wild type and with the antibody applied to $\alpha_{\mathrm{o}}$ or $\alpha_{\mathrm{o} 2}$ null mice. Thus, the antibody for $\alpha_{\mathrm{o} 2}$, under our staining conditions, was unsuitable for immunocytochemistry. Instead, we used three antibodies shown by Western blots to recognize both $\alpha_{\mathrm{o} 1}$ and $\alpha_{\mathrm{o} 2}$ and applied them to retina of the $\alpha_{\mathrm{o} 1}$ null mouse. The monoclonal antibody gave no staining. However, the other two antibodies that recognize both splice variants, one against the CT and one against the NT, both gave faint staining in the OPL, bipolar somas, and stratum 1 of the IPL (Fig. 4C,D). To distinguish this stain from background, we first imaged staining from the $\alpha_{\mathrm{o}}$ null retina. This general background served as a reference at the confocal microscope (Fig. $4 E$ ). Then, using the same laser intensity and gain parameters, we imaged staining from the $\alpha_{\mathrm{o} 1}$ null retina. For both CT and NT antibodies, staining was stronger than in $\alpha_{\mathrm{o}}$ null retina, and the pattern was repeatable (Fig. 4, compare $E$ with $C, D$ ). Both antibodies applied to the $\alpha_{\mathrm{o} 2}$ null retina gave identical staining as in the wild type (Fig. $4 F$ ). Thus, both by in situ hybridization and by immunocytochemistry, bipolar cells weakly express $\alpha_{\mathrm{o} 2}$.

Next, to determine whether the stained bipolar cells represent only a subset of bipolar cells, we stained the $\alpha_{\mathrm{o} 1}$ null retina for PKC and anti- $\alpha_{\mathrm{o}}$ (C terminus). All cells that stained for PKC also stained for $\alpha_{\mathrm{o}}$, but $\sim 8 \%$ of the cells (13 of 75 in one animal; 1 of 100 in the other) that stained for $\alpha_{\mathrm{o}}$ were unstained for PKC (Fig. 5 ). The difference between the two animals could be attributed to weaker expression in cone bipolar cells or to regional differences. The cells that are $\alpha_{\mathrm{o} 2}$ positive (but PKC negative) were not identified. We can rule out the possibility that they are OFF bipolar cells because it has been established (using the same antibody as in this experiment) that $\alpha_{\mathrm{o}}$ is absent from OFF cone bipolar cells (Vardi, 1998). Thus, $\alpha_{\mathrm{o} 2}$ is expressed in rod bipolar cells and in at least some ON cone bipolar cells.

\section{The light response requires $\alpha_{\text {o1 }}$ but not $\alpha_{\text {o2 }}$}

To test which splice variant is crucial for the ON bipolar cell light response, we examined the electroretinogram in mice lacking either $\alpha_{\mathrm{o} 1}$ or $\alpha_{\mathrm{o} 2}$. Three different lighting conditions were used: scotopic (dark adapted plus dim stimulus), saturated (dark adapted plus saturating stimulus), and photopic (light adapted plus strong stimulus). Under all conditions, mice lacking $\alpha_{\mathrm{o} 1}$ also lacked the b-wave, which is generated by the ON bipolar cells (Robson and Frishman, 1995) (Fig. 6, middle column; two animals, four eyes). This lack of b-wave does not reflect lack of photoreceptor activity because the a-wave, which originates in suppression of the photoreceptor dark current (Hagins et al., 1970; Hood and Birch, 1993; Breton et al., 1994; Lyubarsky and Pugh, 1996; Pugh et al., 1998), was present. Under the "saturated" condition, $\alpha_{\mathrm{o} 1}$ null mice gave a reduced, but still profound, a-wave $(78 \pm 34 \mu \mathrm{V})$. Under photopic conditions, in which the negative wave is likely a combination of a-wave and OFF bipolar response, 

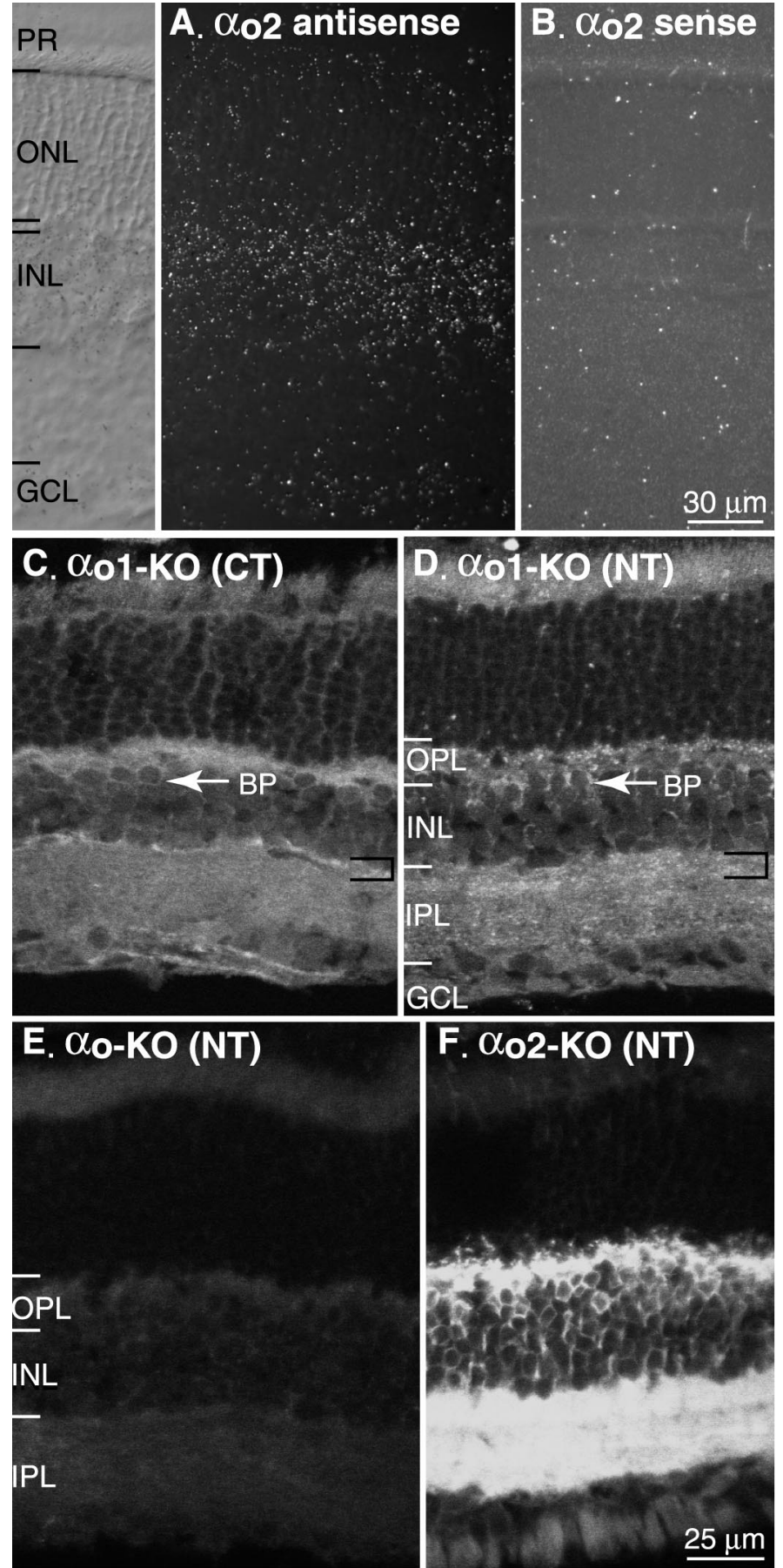

Figure 4. Bipolar cells and stratum 1 of the IPL weakly express the $\alpha_{\mathrm{o} 2}$ splice variant. $A, B$, In situ hybridization (rat). Antisense probes specific for $\alpha_{\mathrm{O} 2}$ message hybridized strongly in the INL and weakly in the ganglion cell layer $(G C L)$. Sense probes gave weak, diffuse background. Left, Differential interference contrast for retinal section in $A$. $C-F$, Immunostaining of mouse retina, visualized with FITC. $D-F$ were captured using the same confocal laser intensity and gain parameters. $C$, Antibody against the CT peptide of $\alpha_{\mathrm{o} 1}$ applied to the $\alpha_{\mathrm{o} 1}$ null retina faintly stained the OPL, bipolar somas $(B P)$, and stratum 1 of the IPL (brackets). D, Antibody against the NT peptide applied to the $\alpha_{\mathrm{o} 1}$ null retina gave similar staining: faint in the OPL, bipolar somas, and puncta throughout the IPL, plus more intense staining in stratum 1. E, NT antibody applied to $\alpha_{\mathrm{o}}$ knock-out $(K O)$ retina gave weak diff use background staining. $F, \mathrm{NT}$ antibody applied to $\alpha_{\mathrm{o} 2}$ knock-out retina gave strong labeling, resembling that obtained with this and other anti- $\alpha_{\mathrm{o}}$ antibodies in wild-type retina.
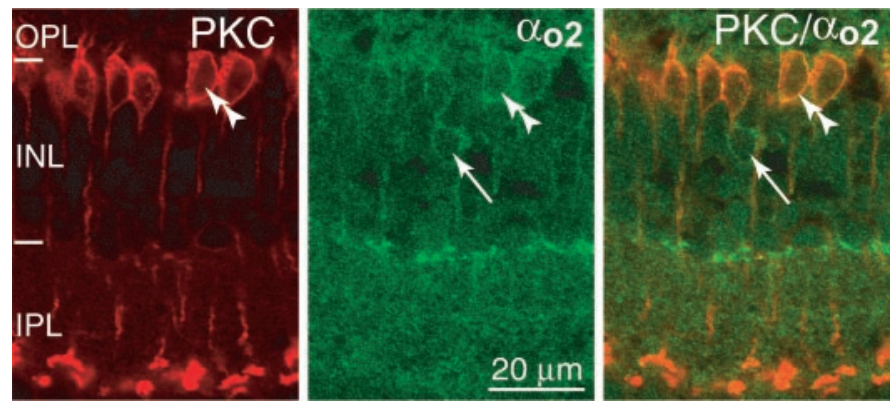

Figure 5. Rod bipolar and some cone bipolar cells stain for $\mathrm{G} \alpha_{\mathrm{o} 2}$. Rod bipolar cells were identified by staining for PKC; staining for $\alpha_{\mathrm{O} 2}$ was achieved by staining an $\alpha_{\mathrm{o} 1}$ null mouse with anti-G $\alpha_{\mathrm{o}}-\mathrm{CT}$. All bipolar somas stained for PKC also stained for $\alpha_{\mathrm{o} 2}$ (double arrowhead), but some somas were stained only for $\alpha_{\mathrm{o} 2}$ (arrow).

the negative wave was as large or greater than in the wild type. This response pattern resembled that obtained when both splice variants were eliminated ( $\alpha_{\mathrm{o}}$ null) (Dhingra et al., 2000). Light responses in mice lacking $\alpha_{\mathrm{o} 2}$ were indistinguishable from wild type (Fig. 6, compare left with right columns; three animals, six eyes). The average peaks for $\mathrm{G} \alpha_{\mathrm{o} 2}$ null mouse versus wild type were as follows (respectively, in microvolts): rod-generated b-wave, $249 \pm 89$ versus $220 \pm 72$; saturated a-wave, $283 \pm 51$ versus $319 \pm 97$; and cone-generated b-wave, $146 \pm 49$ versus $109 \pm 32$.

\section{DISCUSSION}

We showed by several techniques (RT-PCR, Western blotting, in situ hybridization, and immunostaining with antibodies directed against different domains) that both splice variants of $\mathrm{G} \alpha_{\mathrm{o}}, \mathrm{G} \alpha_{\mathrm{o} 1}$ and $\mathrm{G} \alpha_{\mathrm{o} 2}$, are expressed in retinal ON bipolar cells. However, $\mathrm{G} \alpha_{\mathrm{o} 1}$ is much more abundant and is essential for the bipolar cell light response. Mice lacking the $\mathrm{G} \alpha_{\mathrm{o} 1}$ splice variant are devoid of the scotopic and photopic b-waves, whereas mice lacking the $\mathrm{G} \alpha_{\mathrm{o} 2}$ splice variant show a normal ERG. We noticed that the rod a-wave in the $\alpha_{\mathrm{o} 1}$ null mouse was reduced relative to the wild type. The difference is not clear and seems insignificant because in the complete $\mathrm{G} \alpha_{\mathrm{o}}$ null, both a-waves were within normal range. Nevertheless, the lower amplitude does not compromise the conclusion that the response of the bipolar cell is absent because this range of photoresponses should have elicited a b-wave ON response. Thus, the ON responses in rod and all ON cone bipolar cells depend only on $\mathrm{G}_{\mathrm{o} 1}$.

\section{Importance of identifying the crucial splice variant in the mGluR6 cascade}

The identification of $\alpha_{\mathrm{o} 1}$ as the critical splice variant permitted its use (in constitutively active form) as bait in a yeast two-hybrid assay. One strong interactor encodes the $\gamma$ subunit of the photoreceptor phosphodiesterase (PDE6). However, available probes for PDE- $\gamma$ did not localize it to ON bipolar cells, and therefore it is unlikely to be the effector in the ON response (Nawy, 1999). Another interactor encodes Ret-RGS1 (regulator of G-protein signaling), and this protein is expressed in dendritic tips of at least one type of ON cone bipolar cell (Dhingra et al., 2001). Ret-RGS is unlikely to be the actual effector for $\mathrm{G} \alpha_{\mathrm{o} 1}$, although it may assist. Nevertheless, these preliminary observations suggest the value of having narrowed down the search for effectors for the specific splice variant of $\alpha_{\mathrm{o}}$. 


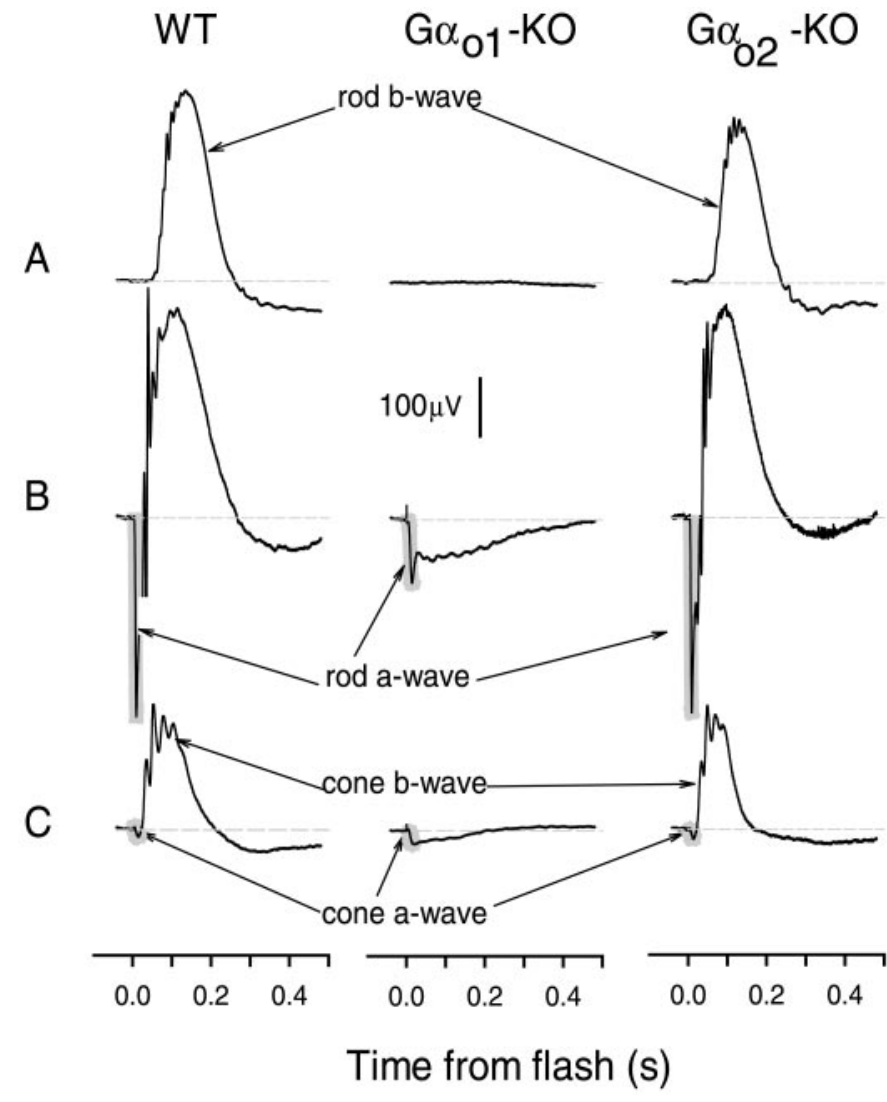

Figure 6. Rod- and cone-driven b-waves are present in the electroretinogram of $\mathrm{G} \alpha_{\mathrm{o} 2}$ null mouse but absent from the $\mathrm{G} \alpha_{\mathrm{o} 1}$ null mouse. $A$, Animals dark adapted for $2 \mathrm{hr}$ were stimulated with dim flashes that elicited a rod-driven, corneal-positive b-wave in the wild-type mouse and in $\mathrm{G} \alpha_{\mathrm{o} 2}$ null but not in the $\mathrm{G} \alpha_{\mathrm{o} 1}$ null. Flash intensities estimated as photoisomerizations $\left(R^{*}\right)$ per rod $(\Phi)$, and number of responses $(n)$ averaged for each trace were as follows: $\Phi=9 ; n=18$. $B$, Dark-adapted animals were stimulated with an intense flash isomerizing $\sim 0.1 \%$ of the rhodopsin. This elicited in wild-type and $\mathrm{G} \alpha_{\mathrm{o} 2}$ null mice a negative a-wave (shading), followed by a positive b-wave. The $\mathrm{G} \alpha_{\mathrm{o} 1}$ null mice showed an a-wave (although somewhat reduced) but no b-wave. $\Phi=10^{5}$; $n=4$. $C$, Mice were adapted to a background (white light, $9100 R^{*} \operatorname{rod}^{-1}$ $\mathrm{sec}^{-1}$ ) that completely suppressed the rod cGMP-activated current. Rods were then stimulated with an intense white flash that isomerized $\sim 0.4 \%$ of the M-cone pigment and $0.03 \%$ of the UV-cone pigment. All of the animals showed a cone-driven a-wave. A typical cone-driven b-wave (positive-going response with superimposed oscillations, peaking $\sim 70-90$ msec after the flash) was present in wild-type and $\alpha_{\mathrm{o} 2}$ null mice but was absent in the $\mathrm{G} \alpha_{\mathrm{o} 1}$ null animals. For all of the records, $n=16 . K O$, Knock-out; $W T$, wild type.

\section{Possible function of $G_{02}$ in ON bipolar cells}

If only $\mathrm{G}_{\mathrm{o} 1}$ is crucial for the $\mathrm{ON}$ response, what is the function of $\mathrm{G}_{\mathrm{o} 2}$ ? We propose several possibilities. (1) $\mathrm{G} \alpha_{\mathrm{o} 2}$ may contribute to fine-tuning of the mGluR6 cascade in certain ON bipolar cells. The ON bipolar cells are classified into rod bipolar cells and approximately five different types of cone bipolar cells that differ by their morphology (Cohen and Sterling, 1990; Boycott and Wässle, 1991; Euler and Wässle, 1995), and they are thought to divide the range of temporal frequencies by responding with different kinetics (Sterling, 1998; Freed, 2000a,b; Masland, 2001; Roska and Werblin, 2001). All ON bipolar cells express the same receptor (mGluR6) (Masu et al., 1995; Vardi and Morigiwa, 1997; Vardi et al., 2000), and the same G-protein $\alpha$ subunit $\left(\alpha_{\mathrm{o} 1}\right)$ and $\gamma$ subunit $\left(\mathrm{G} \gamma_{13}\right)$ (Huang et al., 2000). Because $\mathrm{G} \alpha_{\mathrm{o} 2}$ is expressed only in a subtype of the ON bipolar cells, it may differentially contribute to shaping response kinetics. (2) $\mathrm{G} \alpha_{\mathrm{o} 2}$ could couple different receptors to different biochemical cascades. $\mathrm{G} \alpha_{\mathrm{o} 1}$ and $\mathrm{G} \alpha_{\mathrm{o} 2}$ differ in the $\mathrm{C}$-terminal domain that is generally involved in specific interaction with the receptor and the effector (Conklin et al., 1996). An example for effector specificity is given by Helisoma neurons, in which $\alpha_{\mathrm{o} 2}$, but not $\alpha_{\mathrm{o} 1}$, inhibits $\mathrm{Ca}^{2+}$ channels (ManSon-Hing et al., 1992). An example for receptor specificity is given by rat pituitary $\mathrm{GH} 3$ cells, in which $\mathrm{G}_{\mathrm{o} 1}$ inhibits the $\mathrm{Ca}^{2+}$ channel by coupling muscarinic receptor, whereas $G_{\mathrm{o} 2}$ inhibits this channel by coupling somatostatin receptors (Kleuss et al., 1991; Chen and Clarke, 1996; Degtiar et al., 1997). In rat retina, rod bipolar cells and a subset of cone bipolar cells express, in addition to mGluR6, the metabotropic glutamate receptors mGluR1 and mGluR5 (Koulen et al., 1997). Therefore, it is possible that $G_{\mathrm{o} 2}$ couples these receptors to a second-messenger cascade. Because these receptors typically regulate intracellular $\left[\mathrm{Ca}^{2+}\right]$ (via PLC pathway) (Abe et al., 1992) and because intracellular $\left[\mathrm{Ca}^{2+}\right]$ is critical for adaptation in rod bipolar cells (Shiells and Falk, 1999; Nawy, 2000; Berntson and Taylor, 2000), $\mathrm{G}_{\mathrm{o} 2}$ may contribute to adaptation. (3) $\mathrm{G}_{\mathrm{o} 2}$ may be involved in some aspects of development. Expression patterns of $\mathrm{G}_{\mathrm{o} 1}$ and $\mathrm{G}_{\mathrm{o} 2}$ during development suggest that it mediates several processes in development (Strittmatter et al., 1990; Rouot et al., 1992; DucGoiran et al., 1999). Thus, similar function may apply also in retina. It is important, however, to note that whatever the function in development of $\mathrm{G}_{\mathrm{o}}$ is, it is not crucial for gross morphology because all of the $\alpha_{\mathrm{o}}$ knock-outs $\left(\mathrm{G} \alpha_{\mathrm{o}}-/-, \mathrm{G} \alpha_{\mathrm{o} 1}-/-\right.$, and $\mathrm{G} \alpha_{\mathrm{o} 2}-/-$ ) have normal brain and retinal morphology (Valenzuela et al., 1997; Jiang et al., 1998; Dhingra et al., 2000; this study).

\section{REFERENCES}

Abe T, Sugihara H, Nawa H, Shigemoto R, Mizuno N, Nakanishi S (1992) Molecular characterization of a novel metabotropic glutamate receptor mGluR5 coupled to inositol phosphate $/ \mathrm{Ca}^{2+}$ signal transduction. J Biol Chem 267:13361-13668.

Berntson A, Taylor WR (2000) Response characteristics and receptive field widths of on-bipolar cells in the mouse retina. J Physiol (Lond) 524.3:879-889.

Boycott BB, Wässle H (1991) Morphological classification of bipolar cells of the primate retina. Eur J Neurosci 3:1069-1088.

Breton ME, Schueller AW, Lamb TD, Pugh Jr EN (1994) Analysis of ERG a-wave amplification and kinetics in terms of the G-protein cascade of phototransduction. Invest Ophthalmol Vis Sci 35:295-309.

Chang KJ, Pugh W, Blanchard SG, McDermed J, Tam JP (1988) Antibody specific to the alpha subunit of the guanine nucleotide-binding regulatory protein Go: developmental appearance and immunocytochemical localization in brain. Proc Natl Acad Sci USA 85:4929-4933

Chen C, Clarke IJ (1996) G(o)-2 protein mediates the reduction in $\mathrm{Ca}^{2+}$ currents by somatostatin in cultured ovine somatotrophs. J Physiol (Lond) 491:21-29.

Chomczynski P, Sacchi N (1987) Single-step method of RNA isolation by acid guanidinium thiocyanate-phenol-chloroform extraction. Anal Biochem 162:156-159.

Clapham DE (1996) The G-protein nanomachine. Nature 379:297-299.

Codina J, Grenet D, Chang KJ, Birnbaumer L (1991) Urea gradient/ SDS-PAGE; a useful tool in the investigation of signal transducing $\mathrm{G}$ proteins. J Recept Res 11:587-601.

Cohen E, Sterling P (1990) Demonstration of cell types among cone bipolar neurons of cat retina. Philos Trans R Soc Lond B Biol Sci 330:305-321.

Conklin BR, Herzmark P, Ishida S, Voyno-Yasenetskaya TA, Sun Y, Farfel Z, Bourne HR (1996) Carboxyl-terminal mutations of Gq alpha and Gs alpha that alter the fidelity of receptor activation. Mol Pharmacol 50:885-890.

Degtiar VE, Harhammer R, Nurnberg B (1997) Receptors couple to L-type calcium channels via distinct Go proteins in rat neuroendocrine cell lines. J Physiol (Lond) 502:321-333.

de la Villa P, Kurahashi T, Kaneko A (1995) L-glutamate-induced responses and cGMP-activated channels in three subtypes of retinal bipolar cells dissociated from the cat. J Neurosci 15:3571-3582.

Dhingra A, Lyubarsky A, Jiang M, Pugh Jr EN, Birnbaumer L, Sterling P, 
Vardi N (2000) The light response of ON bipolar neurons requires

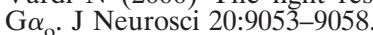

Dhingra A, Faurobert E, Hui J, Sterling P, Vardi N (2001) Localization and possible function of Ret-RGS1 in retina. Soc Neurosci Abstr 27:889.11.

Dolphin AC (1998) Mechanisms of modulation of voltage-dependent calcium channels by G-proteins. J Physiol (Lond) 506:3-11.

Duc-Goiran P, Bourgeois C, Mignot TM, Robert B, Tanguy G, Ferre F (1999) Identification and expression of Go1 and Go2 alpha-subunit transcripts in human myometrium in relation to pregnancy. Biol Reprod 60:1528-1535.

Euler T, Wässle H (1995) Immunocytochemical identification of cone bipolar cells in the rat retina. J Comp Neurol 361:461-478.

Euler T, Schneider H, Wässle H (1996) Glutamate responses of bipolar cells in a slice preparation of the rat retina. J Neurosci 16:2934-2944.

Freed MA (2000a) Parallel cone bipolar pathways to ganglion cell use different rates of and amplitudes of quantal excitation. J Neurosci 20:3956-3963.

Freed MA (2000b) Rate of quantal excitation to a retinal ganglion cell evoked by sensory input. J Neurophysiol 83:2956-2966

Goldsmith P, Backlund Jr PS, Rossiter K, Carter A, Milligan G, Unson CG, Spiegel A (1988) Purification of heterotrimeric GTP-binding proteins from brain: identification of a novel form of Go. Biochemistry 27:7085-7090.

Gudermann T, Schoneberg T, Schultz G (1997) Functional and structural complexity of signal transduction via G-protein-coupled receptors. Annu Rev Neurosci 20:399-427.

Hagins WA, Penn RD, Yoshikami Y (1970) Dark current and photocurrent in retinal rods. Biophys J 10:380-412.

Hood DC, Birch DG (1993) Human cone receptor activity: the leading edge of the a-wave and models of receptor activity. Vis Neurosci 10:857-871.

Horn DA, Latchman DS (1993) Alternative splicing of the mRNA encoding the alpha subunits of the G(o) GTP-binding protein during brain development and in neuronal cell lines. Neurosci Lett 155:57-60.

Hsu WH, Rudolph U, Sanford J, Bertrand P, Olate J, Nelson C, Moss LG, Boyd AE, Codina J, Birnbaumer L (1990) Molecular cloning of a novel splice variant of the alpha subunit of the mammalian $G_{0}$ protein. J Biol Chem 265:11220-11226.

Huang L, Euler T, Su H, Masland RH, Max M, Margolskee RF (2000) A newly identified G-protein $\gamma$ subunit, G $\gamma 13$, is selectively expressed in retinal ON bipolar cells. Soc Neurosci Abstr 26:248.7.

Jiang M, Gold MS, Boulay G, Spicher K, Peyton M, Brabet P, Srinivasan Y, Rudolph U, Ellison G, Birnbaumer L (1998) Multiple neurological abnormalities in mice deficient in the G-protein $\mathrm{G}_{\mathrm{o}}$. Proc Natl Acad Sci USA 95:3269-3274.

Jiang M, Spicher K, Boulay G, Martin-Requero A, Dye CM, Rudolph U, Birnbaumer L (2002) Mouse gene knockout and knockin strategies and methods in application to alpha subunits of the Gi/Go family of $\mathrm{G}$ proteins. Methods Enzymol 244-277-298

Kleuss C, Hescheler J, Ewel C, Rosenthal W, Schultz G, Wittig B (1991) Assignment of G-protein subtypes to specific receptors inducing inhibition of calcium currents. Nature 353:43-48.

Koulen P, Kuhn R, Wässle H, Brandstätter JH (1997) Group I metabotropic glutamate receptors mGluR $1 \alpha$ and mGluR5a: localization in both synaptic layers of the rat retina. J Neurosci 17:2200-2211.

Li X, Mumby S, Greenwood A, Jope R (1995) Pertussis toxin-sensitive G-protein $\alpha$-subunits: production of monoclonal antibodies and detection of differential increases upon differentiation of PC12 and LA-N-5 cells. J Neurochem 64:1107-1117.

Lyubarsky AL, Pugh Jr EN (1996) Recovery phase of the murine rod photoresponse reconstructed from electroretinographic recordings. J Neurosci 16:563-571.

Lyubarsky AL, Falsini B, Pennesi ME, Valentini P, Pugh Jr EN (1999) $\mathrm{UV}$ - and midwave-sensitive cone-driven retinal responses of the mouse: a possible phenotype for coexpression of cone photopigments. J Neurosci 19:442-455.

Lyubarsky AL, Chen CK, Simon MI, Pugh Jr EN (2000) Mice lacking G-protein receptor kinase 1 have profoundly slowed recovery of conedriven retinal responses. J Neurosci 20:2209-2217.

Lyubarsky AL, Lem J, Chen J, Falsini B, Iannaccone A, Pugh EN (2002) Functionally rodless mice: transgenic models for the investigation of cone function in retinal disease and therapy. Vision Res 42:401-415.

Man-Son-Hing HJ, Codina J, Abramowitz J, Haydon PG (1992) Microinjection of the alpha-subunit of the G-protein Go2, but not Go1, reduces a voltage-sensitive calcium current. Cell Signal 4:429-441.

Masland RH (2001) The fundamental plan of the retina. Nat Neurosci 4:877-886.

Masu M, Iwakabe H, Tagawa Y, Miyoshi T, Yamashita M, Fukuda Y, Sasaki H, Hiroi K, Nakamura Y, Shigemoto R (1995) Specific deficit on the $\mathrm{ON}$ response in visual transmission by targeted disruption of the mGluR6 gene. Cell 80:757-765.

Nawy S (1999) The metabotropic receptor mGluR6 may signal through $\mathrm{G}_{\mathrm{o}}$, but not phosphodiesterase, in retinal bipolar cells. $\mathrm{J}$ Neurosci 19:2938-2944.

Nawy S (2000) Regulation of the on bipolar cell mGluR6 pathway by $\mathrm{Ca}^{2+}$. J Neurosci 20:4471-4479.

Nawy S, Jahr CE (1990) Suppression by glutamate of cGMP-activated conductance in retinal bipolar cells. Nature 346:269-271.

Neer EJ (1994) G-proteins: critical control points for transmembrane signals. Protein Sci 3:3-14.

Nomura A, Shigemoto R, Nakamura Y, Okamoto N, Mizuno N, Nakanishi S (1994) Developmentally-regulated postsynaptic localization of a metabotropic glutamate-receptor in rat rod bipolar cells. Cell 77:361-369

Pugh Jr EN, Falsini B, Lyubarsky A (1998) The origin of the major rodand cone-driven components of the rodent electroretinogram and the effect of age and light-rearing history on the magnitude of these components. In: Photostasis and related phenomena (Williams T, Thistle A, eds), pp 93-128. New York: Plenum.

Robson JG, Frishman LJ (1995) Response linearity and kinetics of the cat retina: the bipolar cell component of the dark-adapted electroretinogram. Vis Neurosci 12:837-850.

Roska B, Werblin F (2001) Vertical interactions across ten parallel, stacked representations in the mammalian retina. Nature 410:583-587.

Rouot B, Charpentier N, Chabbert C, Carrette J, Zumbihl R, Bockaert J, Homburger V (1992) Specific antibodies against Go isoforms reveal the early expression of the Go2 alpha subunit and appearance of Go1 alpha during neuronal differentiation. Mol Pharmacol 41:273-280.

Rudolph U, Brabet P, Hasty P, Bradley A, Birnbaumer L (1993) Disruption of the G(i2) alpha locus in embryonic stem cells and mice: a modified hit and run strategy with detection by a PCR dependent on gap repair. Transgenic Res 2:345-355.

Rudolph U, Bradley A, Birnbaumer L (1994) Targeted inactivation of the Gi2 alpha gene with replacement and insertion vectors: analysis in a 96-well plate format. Methods Enzymol 237:366-386.

Shiells RA, Falk G (1990) Glutamate receptors of rod bipolar cells are linked to a cyclic GMP cascade via a G-protein. Proc R Soc Lond B Biol Sci 242:91-94.

Shiells RA, Falk G (1999) A rise in intracellular Ca ${ }^{2+}$ underlies light adaptation in dogfish retinal 'on' bipolar cells. J Physiol (Lond) 514:343-350.

Sterling P (1998) Retina. In: The synaptic organization of the brain (Shepherd GM, ed), pp 205-253. New York: Oxford UP.

Strathmann M, Wilkie TM, Simon MI (1990) Alternative splicing produces transcripts encoding two forms of the alpha subunit of GTPbinding protein Go. Proc Natl Acad Sci USA 87:6477-6481.

Strittmatter SM, Valenzuela D, Kennedy TE, Neer EJ, Fishman MC (1990) Go is a major growth cone protein subject to regulation by GAP-43. Nature 344:836-841.

Tsukamoto T, Toyama R, Itoh H, Kozasa T, Matsuoka M, Kaziro Y (1991) Structure of the human gene and two rat cDNAs encoding the alpha chain of GTP-binding regulatory protein Go: two different $\mathrm{mR}$ NAs are generated by alternative splicing. Proc Natl Acad Sci USA 88:2974-2978.

Valenzuela D, Han X, Mende U, Fankhauser C, Mashimo H, Huang P, Pfeffer J, Neer EJ, Fishman MC (1997) G alpha is necessary for muscarinic regulation of $\mathrm{Ca}^{2+}$ channels in mouse heart. Proc Natl Acad Sci USA 94:1727-1732.

Vardi N (1998) Alpha subunit of $\mathrm{G}_{\mathrm{o}}$ localizes in the dendritic tips of ON bipolar cells. J Comp Neurol 395:43-52.

Vardi N, Morigiwa K (1997) ON cone bipolar cells in rat express the metabotropic receptor mGluR6. Vis Neurosci 14:789-794.

Vardi N, Matesic DF, Manning DR, Liebman PA, Sterling P (1993) Identification of a G-protein in depolarizing rod bipolar cells. Vis Neurosci 10:473-478.

Vardi N, Morigiwa K, Wang T-L, Shi Y-J, Sterling P (1998) Neurochemistry of the mammalian cone "synaptic complex." Vision Res 38:1359-1369.

Vardi N, Duvoisin RM, Wu G, Sterling P (2000) Localization of mGluR6 to dendrites of ON bipolar cells in primate retina. J Comp Neurol 423:402-412.

Weng K, Lu C-C, Daggett LP, Kuhn R, Flor PJ, Johnson ED, Robinson PR (1997) Functional coupling of a human retinal metabotropic glutamate receptor (hmGluR6) to bovine rod transducin and rat $\mathrm{G}_{\mathrm{o}}$ in an in vitro reconstruction system. J Biol Chem 272:33100-33104.

Wu SM, Gao F, Maple BR (2000) Functional architecture of synapses in the inner retina: segregation of visual signals by stratification of bipolar cell axon terminals. J Neurosci 20:4462-4470. 